\title{
Having Burned the Straw Man of Christian Spiritual Leadership, what can We Learn from Jesus About Leading Ethically?
}

\author{
Christopher Mabey $^{1} \cdot$ Mervyn Conroy $^{2} \cdot$ Karen Blakeley $^{3} \cdot$ Sara de Marco $^{1}$
}

Received: 25 June 2015/ Accepted: 28 January 2016/Published online: 17 February 2016

(C) The Author(s) 2016. This article is published with open access at Springerlink.com

\begin{abstract}
In considering what it means to lead organizations effectively and ethically, the literature comprising spirituality at work (SAW) and spiritual leadership theory (SLT) has become highly influential, especially in the USA. It has also attracted significant criticism. While in this paper, we endorse this critique, we argue that the strand of literature which purportedly takes a Christian standpoint within the wider SAW school of thought, largely misconstrues and misapplies the teaching of its founder, Jesus. As a result, in dismissing the claims and application of SAW and SLT, there is a real risk that we lose the vital contribution of Christian thought, not least some of the timeless counter-cultural wisdom of Jesus which, we contend, offers a vital foundation to the practice of ethical leadership and business ethics in organizations. In proposing a way forward, two thorny issues which face all leaders are addressed: dealing with ego and closing the gap between what we say and what we do. The more we understand about the dynamics of human nature, the more we learn about the profundity of Jesus' teachings. We then propose a number of ways in which Jesus-centred ethical leadership can be practised. Each is radical and each implies risk: both the
\end{abstract}

Christopher Mabey

c.mabey@mdx.ac.uk

Mervyn Conroy

m.conroy@bham.ac.uk

Karen Blakeley

Karen.Blakeley@winchester.ac.uk

Sara de Marco

S.DeMarco@mdx.ac.uk

1 Middlesex University Business School, Hendon,

London NW4 4BT, UK

2 Birmingham University, Birmingham, UK

3 Winchester University Business School, Winchester, UK personal risk of inner renewal arising from repentance as a doorway to personal integrity, as well as the risk of opposing unethical practices and promoting the excellence of core practices in the workplace.

Keywords Spirituality at work - Jesus-centred business ethics $\cdot$ Ethical leadership $\cdot$ Spiritual leadership

\section{Introduction}

The growing literature on spiritual approaches to work (SAW) and spiritual leadership theory (SLT) (Delbecq 1999; Eisler and Montouori 2003; Freshman 1999; Fry and Cohen 2009; Giacalone and Jurkiewicz 2003; WagnerMarsh and Conley 1999) has attracted criticism on a number of levels: its appropriation of spiritual approaches for instrumental purposes (Casey 2002; Bell and Taylor 2003; Zhuravleva and Jones 2006), its reduction to what Jacques Ellul calls 'technique', a limited form of economic rationality (Driscoll and Wiebe 2007), its attempt to theorize and operationalize workplace spiritually from a hypothetico-deductive standpoint (Case and Gosling 2010; Case et al. 2012), the failure of leadership development to engage with non-functionalist ontologies (Lips-Wiersma and Mills 2014; Mabey 2013) and its treatment of spirituality devoid of historical and political context (Nash 2003a, b; Porth et al. 2003). Perhaps the most strident and comprehensive critique comes from Tourish and Tourish (2010) who condemn the managerialist presumption underlying SAW literature. This critique has constituted a powerful and damaging attack on the $\mathrm{SAW}$ and $\mathrm{SL}^{1}$

\footnotetext{
${ }^{1}$ When we use the term SAW we mean it to include the literature on spiritual leadership (SL).
} 
literature which is unfortunate as research into spirituality has the potential to make a considerable contribution to business ethics.

In this paper, we seek to achieve three objectives. In the first section, we burn the straw man of Christian spirituality arising from the generic SAW literature and distinguish from these claims a specifically Jesus-centred interpretation of spiritual leadership. In the spirit of advancing, a "more nuanced theorisation of the field... along with interpretative approaches that reflect the subtlety of the terrain" (Case and Gosling 2010, p. 259), we believe this clarification will have important ramifications in advancing an alternative approach to ethical leadership in the workplace while helping to avoid some of "the ethical damage in the name of workplace spirituality" that these authors highlight.

In the second section, we propose a model that links personal spirituality to ethical leadership in business, drawing on Treviño et al.'s (2003) distinction between the moral person and moral manager and Moore's (2008) ideas around re-imagining the morality of the manager. By drawing on these two sources, we argue that the source teachings of Jesus provide a spiritual foundation for ethical leadership in a way that redresses some the criticisms levelled at the generic spiritual literature, particularly those that argue that the SAW writings are instrumental and ahistorical in nature. We argue that this Jesus-centred approach to leadership has the potential to help executives develop integrity while countering those forces that contribute to the emergence of the dark side of leadership (Tourish 2013) namely hubris, greed and egotism.

The third objective, in the final section of the paper, is to offer five practical, if challenging, ways forward arising from the teaching and example of Jesus, for those who wish to pursue more ethically based leadership.

\section{Burning the Straw Man of Christian Spiritual Leadership}

In chapter 4 of his book, The Dark Side of Transformational Leadership Tourish (2013) comprehensively and critically dissects the SAW literature which has grown in prominence over the last decade in the USA. As he points out, this writing invokes spirituality in the workplace, with particular regard to leadership development and usually, though not exclusively, from a Christian perspective. ${ }^{2}$ In this paper, we take issue with Tourish, not because we believe his critique is flawed-indeed it is timely and

\footnotetext{
2 Tourish regards the dominant discourse within SAW literature to be that concerned with God, and specifically he notes that: "spirituality is generally synonymous with a Christian belief system" (2013, p. 67).
}

among the most cogently articulated that we have encountered-but because the target of his analysis is misplaced. SAW, to the extent that it can be called a coherent movement, ${ }^{3}$ indeed extols a spiritually and ethically informed approach to leadership, but our contention is that the strand of literature which purportedly takes a Christian standpoint within the wider SAW school of thought, largely misconstrues and misapplies the teaching of its founder, Jesus. ${ }^{4}$ So while Tourish, among others (Carette and King 2005; Case and Gosling 2010) is persuasive in his suspicion of SAW and associated SLT, we suggest that what is being addressed is actually a "straw man' of spiritual leadership as it pertains to Christian beliefs. The danger is that in highlighting the flaws in and dismissing the leadership theories arising from SAW and SLT, we risk overlooking or obfuscating the original wisdom upon which the Christian stream of such writing is supposedly based. Why is this important? Because this original wisdom, contained in the New Testament scriptures and embodied in the teaching and lifestyle of Jesus speaks very powerfully and pertinently into current leadership debates, which are currently pre-occupied with issues of authenticity (Gardner et al. 2011), character (Crossan et al. 2013), ethics (Brown and Treviño 2006; Schaubroeck et al. 2012) and followership (Collinson 2006). In so doing, we are not, of course, claiming to speak for all Christian believers, nor are we advocating an exclusively Christian stance or decrying the value of other spiritual approaches.

By way of illustration, we now take several of the arguments put forward by Tourish and offer an alternative rendering of how a Christian spiritual approach might further ethical leadership in the workplace.

\section{Monoculturalism}

Tourish claims that SAW: "can be employed as yet another means of establishing monocultural workplace environments, in which employee dissent is demonised as the sinful antithesis of spiritual values... and which organizational leaders are uniquely qualified to articulate" (2013, p. 61). To be sure, this suppression of diversity can and does happen and not infrequently in the name of a

\footnotetext{
${ }^{3}$ In fact, there are various streams to this movement clustering primarily under the Academy of Management "Management, Spirituality and Religion" special interest group.

${ }^{4}$ The primary sources for our understanding of Jesus' leadership come from the four biblical quasi-biographical accounts. While this is of course a selective, theologically motivated set of accounts, it is nevertheless what we now mean by a Christian understanding. When we speak of Jesus' leadership, we are therefore referring to the perceptions of Jesus' leadership among the emerging communities of his earliest followers.
} 
Christian spiritual leadership. Yet the three premises underlying this claim are direct contradictions of what Jesus taught and modelled. Mark opens his "gospel" account with Jesus challenging the ideological hegemony, power and privilege of the legal, moral and religious police (Myers 2008, pp. 152-161), and all four gospels record his eventual lynching for dissidence by the collusive religious and political elite he opposed (Wright 1996, pp. 108, pp. 490-493; Horsley and Silberman 1997, p. 84) and, of course, his resurrection and ultimate vindication. ${ }^{5}$ $\mathrm{He}$ demonstrated supreme courage and humility by breaking the cultural taboos of his time rather than imposing a monocultural mind-set, touching and healing lepers, dining with tax-collectors, treating women as equals, treating prostitutes with dignity, welcoming children, socializing with Samaritans (Myers 2008). And his leadership style was summed up in his personal mission: "this is what the Son of Man has done: He came to serve, not be served-and then to give his life away in exchange for the many who are held hostage" (Bible, Matthew 20:28). ${ }^{6}$ How different the workplace would be where routinized and embedded hierarchies could be questioned and called to account, where the marginalized were listened to and respected and where leaders re-defined themselves as servants at the bottom of the pyramid rather than above reproach at the top (Greenleaf 1971; Nair 1997).

\section{Manipulation}

A second aspect of SAW highlighted by Tourish is: "the focus on the need for individuals to adapt everything they possess, body and soul, to the organizational environment in which they find themselves, in pursuit of meaning and solace. The possibility that such a colonization of people's affective domain might be oppressive, invasive or unwelcome is not generally considered" (2013, p. 66). Again, there is no doubt that leaders are capable of manipulating the hearts and minds of employees for corporate ends, and that this is all the more sinister when done in the name of a particular religious belief system. But is this what Jesus taught? Jesus begins his

\footnotetext{
$\overline{5}$ We should acknowledge that the gospels are largely unintelligible if concepts such as resurrection and kingdom are excluded, but we do not have space to develop these concepts here. For example, further study might explore the leadership implications of Jesus' call to repentance as a call to embrace and to embody the values of the Kingdom, a form of hope in action (Moltmann 2012).

${ }^{6}$ Here and following, we quote the words of Jesus as recorded in the Gospel accounts (using The Message which is a contemporary rendering from the original languages), historically verified and recognized as the canon of the New Testament at the Synod of Hippo in $\mathrm{AD} 393$.
}

ministry with a call to repentance, and it is this focus on repentance that most clearly encapsulates his message. The Greek word for repentance (metanoia) is thus far more radical than feeling regretful and asking for forgiveness, referring rather to the inner transformation of the soul (Bourgeault 2008 , p. 41), which is to be expressed in love for neighbour and solidarity with the oppressed. Jesus' teachings in the Sermon on the Mount invert the world's obsession with material success by placing humility, integrity, kindness, forgiveness, peace and love as core values at the centre of the Christian life (Bible, Matthew 5 and 6) and as tangible expressions of the kingdom of God. As a result of his lifechanging encounter with Jesus, a wealthy businessman who had gained a small fortune through extortion and fraud, declared: "Master, I give away half of my income to the poor-and if I am caught cheating, I pay four times the damages" (Bible, Luke 18:9-10). Jesus commended his changed attitude and accountability, all very apposite given the recent critiques of corporate leaders as greedy, dishonest and hubristic. Too often, the reader imagines that these incitements to live a spiritual life are directed at the powerless, forming an ideological apologia emphasizing conformity and compliance in organizational life. But Jesus aimed his teaching at everyone, particularly those in positions of wealth and influence while realizing that for this latter group, the embodiment of these values was even more difficult than it was for the poor, claiming that it would be easier for a camel to pass through the eye of a needle than it would be for a rich man to enter the Kingdom of God (Bible, Matthew 19:16-30).

Does this emphasis on love, honesty, service, peace and justice imply a teaching of power-hungry leadership desperate to proselytize and dupe followers into a corporately convenient religious ideology? Quite the opposite, Jesus recognizes life to be gritty and bewildering, tortuous and ambiguous, but nevertheless he holds out the hope that life can have deep meaning and enduring significance but this will not be achieved by focusing on the temptations of materialism or status or power. A meaningful life can only be achieved by following Jesus rather than worldly organizational leaders: "I come so that they can have real and eternal life, more and better life than they ever dreamed of" (Bible, John 10:10). In a related parable he tells the story of a merchant willing to sell all he possesses for a pearl of great worth, referring to the rewards of the spiritual as opposed to the material life. Christian leaders and followers will place these values, these loyalties above everything providing an alternative worldview within which to orient their actions, beliefs and sympathies. This implies a radical independence, a willingness to critique wrong-doing and wrong-thinking and in particular a protection against the inducements to flatter, conform, bully, judge and aggrandize the self. 


\section{Materialism}

A further tenet of SAW is that it represents: "a causal leadership theory for organizational transformation designed to create an intrinsically motivated, learning organization" (Fry et al. 2005, p. 835), giving rise to the assertion that: "by embracing spirituality, organizations (that is, senior managers) will improve effectiveness, productivity and profitability" (Tourish 2013, p. 70). So we arrive at the incongruity that organizations are encouraged to enlist increasingly religious values to make more money. Once again, for all its 'Christian' credentials we find, we have travelled a long way from its originator's intent. In building his leadership team, Jesus observed: "Self-help is no help at all. Self-sacrifice is the way, my way, to finding yourself. What kind of deal is it to get all you want but lose yourself. What could you ever trade your soul for?" (Bible, Matthew 16:24), and he demonstrated by his lifestyle as well as his teaching a reliance upon wisdom rather than wealth, a compassion for others as against selfish ambition and a reverence for the created world rather than rapacious greed. To be sure, these values are not necessarily incompatible with effective leadership and success in business but they are immediately diminished when instrumentally and exclusively conscripted to this cause. As Driscoll and Wiebe (2007, p. 342) note: "authentic spirituality in the workplace has to fundamentally question accepted models of economic growth as the relationships between current global economic structures and systems and issues of environmental degradation and work-life imbalance become more obvious... [this] may mean accepting lower profits as a result of integrating spiritual values into the workplace. Morality must guide the means of economic activity, not the other way around." Nor is this message naïve as more and more respected scholars, politicians, economists and journalists question the morality and sustainability of the existing neoliberal models of capitalism (Ghoshal 2005; Hilton 2015; Kaletsky 2010; Harvey 2007).

So, having cleared away some of the misconceptions concerning a distinctively Christian thread of spiritual approaches to work, what positive alternative does a Jesuscentred approach offer and what are the implications for ethical leadership practice?

\section{The Way Forward}

In order to address this question, it is important to point out that while there has been a strong research focus on ethical leadership over the past 20-30 years, (with writing on transformational, servant and authentic leadership going back even longer), the world of practice has generated some of the most notable forms of unethical, leadership we have encountered in modern times (Kellerman 2004; Tourish 2013). In a complex world, it would be naïve to identify simplistic reasons to explain this gap between theory and practice but, with support from current research in social psychology, we argue that one way of addressing the gap is by exploring how the teachings of Jesus provide a personal spiritual foundation for a robust ethical leadership which is much more likely to resist situational pressures or compromise integrity. By focusing on spirituality as inner transformation rather than external exhortation, we also avoid the traps identified by Tourish and other critics of SAW.

Ethical leadership has been defined as "the demonstration of normatively appropriate conduct through personal actions and interpersonal relationships, and the promotion of such conduct to followers through two-way communication, reinforcement, and decision-making" (Brown et al. 2005, p. 120). This definition builds upon Treviño et al. (2003) influential distinction between the moral person and the moral manager. The moral person has a reputation for integrity within both the personal and professional spheres while the moral manager "refers to how the leader uses the tools of the position of leadership to promote ethical conduct at work" (Brown and Mitchell 2010, p. 584). A moral person who lacks moral leadership is perceived as weak and lacking commitment to ethics. A moral leader who lacks integrity in their personal life is seen as hypocritical which reduces their ethical authority in the workplace (Brown and Mitchell 2010, p. 585). In order to lead in an ethical manner, the individual has, first, to cultivate personal integrity including the elements of altruism, fairness and ethical judgement (Liden et al. 2008) $;^{7}$ secondly, to demonstrate these qualities when in a position of power. MacIntyre (1988) advances a further challenge for ethical leaders that of understanding where their ethical position originates. He asks: On whose justice and on which rationality are they basing their standpoint? For MacIntyre, to achieve this understanding requires a tracing of the antecedents of their standpoint; namely, the originating ideology on which their ethical stance is based. He suggests that in order to enact ethics, there must be some philosophical roots to the ethical practice; one cannot simply 'be' ethical in isolation. MacIntyre therefore suggests that it is only through understanding of the wider (ideological) battle of which a leader's ethical dilemmas are but scenes that an ethical purpose can be formed.

\footnotetext{
7 According to Liden et al. (2008), servant leadership differs from traditional approaches to leadership in that it stresses personal integrity and focuses on forming strong long-term relationships with employees, customers and communities.
} 
Moore (2008) draws on MacIntyre's virtue ethics schema to offer a way to establish an ethical purpose. Of Moore's seven points, none address the foundation of a manager's stance. Here we contribute in the way MacIntyre suggests to the underpinning of an ethical leader's stance through a Christian lens. In doing so, we both support and advance Moore's position by suggesting that the source teachings of Jesus speak to the advancement of ethical leadership purpose in a way that redresses some the criticisms levelled at the generic spiritual literature, particularly those arguing that SAW and SLT are instrumental and ahistorical in nature.

In particular, we propose that in order to exhibit ethical leadership, it is beneficial to cultivate a personal spirituality (the moral person) which provides philosophical, emotional and spiritual sustenance to ethical leadership in practice (the moral manager or leader) and without which ethical leadership is more likely to succumb to situational pressures. The cultivation of a personal spirituality need not morph into the promulgation of spirituality in the workplace; rather it is best seen as the root of ethical and indeed authentic, servant and transformational leadership. The leader's spirituality is, essentially, a 'private' matter, something that Jesus insists upon: "When you pray, don't be like those show-offs who love to stand up and pray in the meeting places and on the street corners. They do this just to look good. I can assure you that they already have their reward. When you pray, go into a room alone and close the door. Pray to your Father in private. He knows what is done in private, and he will reward you" (Bible, Matthew 6:5-6).

This distinction between the private and the public, between the moral person and the moral manager/leader is vital and goes a significant way towards addressing the criticisms of the SAW literature. Jesus does not teach us to become spiritual leaders; he teaches us to become spiritual individuals, who rooted in Christ's teachings, will embody love, integrity and service in all we do without having to advertise our spiritual credentials.

Jesus has important things to say about the development of personal spirituality, revealing with insight and acuity the nature of the human heart with regard to two fundamental matters: first, how to deal with the ego, and second, how to reduce the credibility gap between what we say and what we do, hence aligning the moral manager and moral person and better fitting us for ethical leadership.

\section{Dealing with Ego}

Although the language may differ and the 'methods' adopted may vary, most spiritual teachings seek to address the stubborn issue of ego and in so doing, provide one of the most important resources to sustain and support ethical leadership. By ego, we refer to what Kohlberg in adult moral developmental theory might call lower levels of moral development when the individual seeks self-gratification, vigorously promotes its self-interest and generally lacks empathy, self-control, humility or self-sacrifice (Kohlberg 1984). In contrast to attempts to manage, suppress, train or transcend these ego forces, ${ }^{8}$ Jesus is straightforward in claiming that repentance alone will lead to the personal transformation required to effectively constrain these impulses. As noted above, the word repentance is a misleading translation of the word metanoia which actually means to go beyond the human, egotistic mind by allowing God to change us at a deep level. Our leaders are admonished for their lack of integrity, yet gossip, wrongdoing, judgmentalism, anger, lying, competition for status and power, jealousy of our peers, blaming others, avoiding responsibility for our own actions-these are the common actions of many leaders much of the time.

The field of social psychology is replete with studies showing how difficult individuals find it to exercise qualities such as honesty. When given the opportunity to cheat in the knowledge they will not be found out, people have been found to be dishonest (Mazar et al. 2008); people will engage in fraudulent accounting despite having strong values around honesty (Brief et al. 1996); trainee priests are less likely to help people if they are in a hurry even if they have been studying the parable of the Good Samaritan beforehand (Darley and Batson 1973); subjects will lie in order to gain the opportunity of receiving a small sum of money (Bazerman and Gino 2012). This is to say nothing of the famous Stanford Prison experiments (Zimbardo 2008) and Milgram's electric shock experiments which show how violent we can become when we are immersed in an ambiguous or highly constrained situation which triggers our 'ethics blind spots' (Werhane et al. 2011).

If Jesus' words are taken seriously, all people arewithout exception-morally flawed, a point that his followers recognize when they ask Jesus "Who has any chance at all?" Jesus' reply goes to the heart of Christian spirituality and Christian ethics: "No chance at all if you think you can pull it off yourself. Every chance in the world if you trust God to do it" (Bible, Matthew, 19: 25-26). In other words, Jesus is telling would-be leaders

\footnotetext{
${ }^{8}$ For example, Fry and Kriger (2009) describe Spiritual Leadership as a journey through 5 levels of spiritual growth culminating in leadership based on oneness and constant reconciliation. He maintains this journey leads to a shift from ego-centeredness to ego transcendence: the "Spirit is that aspect of one's being that gives rise to the possibility of self-transcendence and deepening connectedness with all things in the universe....this often involves cultivation of spiritual practices such as contemplation, prayer and meditation." (2009, p.1680). Self-transformative exercises can be found in all forms of spirituality, religious and secular, including mindfulness, meditation and askesis (McGushin 2007).
} 
that it is not possible to develop personal integrity, honesty, kindness, fairness and moral judgement by trusting in personal strength—something more than willpower and good intentions is needed. Jesus is quite clear as to how to develop personal integrity. He states that "the Spirit can make life. Sheer muscle and willpower don't make anything happen" (Bible, John 6:63): it is through repentance (inner transformation) and the inspiration of the Holy Spirit within a person, transforming and freeing them from the continual urge to pursue their material self-interests at the expense of their integrity, their character and their soul. How does this happen? In fact, Jesus says little about the qualities particular to ethical leadership, and more about the need for the individual to manifest faith and ask the Holy Spirit into his or her heart in order to do the work of inner transformation. When Nicodemus, a powerful religious, leader visited Jesus secretly under the cloak of darkness, wanting to learn more about Christ and his teachings, Jesus tells him that he must be born again. In response to Nicodemus' confusion at this point Jesus explains: "Unless a person is born from above, it's not possible to see what I am pointing to- to God's kingdom" (Bible, John 3:5).

\section{Reducing the Credibility Gap}

The character of leaders, especially the capacity to restrain and inhibit selfish desires and habits, has been shown to affect whether an organization is led ethically and responsibly (Bragues 2008; Wright and Goodstein 2007). But humans have a problem with power. There is now significant evidence to suggest a relationship between attraction to power (as measured by social dominance orientation) and reduced empathy, compassion and concern for others (Anderson and Brown 2010). People with high social dominance orientation display a preference for hierarchical systems within which their in-group is perceived as superior to out-groups, where power inequalities are both valued and legitimized and where ruthlessness is a necessary and valued trait (Aiello et al. 2013). According to Anderson and Brown (2010) the personality trait of agreeableness is negatively associated with leader emergence but positively associated with leader effectiveness. On the other hand, the simple desire for promotion to senior posts, a facet of social dominance orientation, is associated both with the achievement of power and with high levels of selfishness. Furthermore, the exercise of power increases levels of testosterone while decreasing oxytocin which in turn leads to higher levels of aggression and lower levels of empathy and prosocial behaviour (Israel et al. 2009; Owen 2012; Hogeveen et al. 2014; Robertson 2012).
Clearly something occurs when a person takes on a leadership role such that they may or may not decide to enact their values within their new position. Power appears to impact the brain in such a way as to generate the hubris syndrome-an over-inflated self-opinion and derision for the opinions of others, recklessness, a tendency to treat others as objects and a loss of contact with reality (Owen 2012). This begins to explain why acting with integrity in the workplace is so difficult and especially when exercising leadership. It helps to identify at least one reason for the gap between theory and practice, between what leaders say and what they do and between what we desire in our leaders and what we get. These are the problems that Jesuscentred spirituality directly addresses. What did Jesus have to say about power? He understood what social psychology and neuroscience are just beginning to confirm, that many of those attracted to and successful in gaining power, were in danger of becoming hypocrites, corrupted by power and the least likely to be redeemed.

Jesus is clear that faith and humility are qualities vital to those who exercise power and for ethical leadership whether in the church or in the world. "Kings like to throw their weight around and people with authority like to give themselves fancy titles. It's not going to be that way with you. Let the senior among you become like the junior; let the leaders act the part of the servant" (Bible, Luke $22 \mathrm{v}$ 24-6).

Here he turns popular conception of leadership and power on its head. In the place of a domineering style, he advocates an attitude of serving others, instead of the arrogance that accompanies seniority he calls for the humility of youth (that recognizes it has much to learn), and states that true authority comes from inner convictions rather than outwards status. The wisdom of this approach to leadership has long since been recognized by advocates of servant leadership (Greenleaf 1971) and those theorists who give more prominence to followership (e.g. Collinson 2006; Grint 2000). As two commentators in the field have stated: "We really must look past the charisma and into the motives of the leader. We must look past leader behaviours and into the heart of the leader. We really need to have an insight into leadership for a higher purpose" (Jackson and Parry 2008, p. 98). In her book on leadership, Sinclair reflects on her own experiences of power and powerlessness as a female academic: "While I am not saying that one can ever stand outside of the power relations or structures in which we exist, I am arguing that making these more visible is an empowering thing to do-for oneself and others" (2008, p. 81). Myers (2008) sees Jesus' declaration as pivotal: "No one can enter a strong man's house and plunder his property without first tying up the strong man" (Bible, Mark 3:27). His commitment to spirit did not 
require a silencing of critique; in advocating liberty he did not imply anarchy.

A theme emerging in the leadership literature is the introduction of a virtues-based model: "that places character development at the core of ethical decision making" (Crossan et al. 2013, p. 287). Here, according to these authors, character development emerges though an ongoing process of experiential learning involving the application of virtues, values and character traits together with the skilful management of situational pressures; it is only once the 'moral' person matures, that they can be considered as worthy of a leadership role. A Jesus-centred approach would endorse this with two important caveats. First, as discussed above, the process of character development begins with a radical and inner renewal by the Holy Spirit; second, leadership is not reserved for those with seniority and experience. Like many executives today, Jesus' followers were much exercised by leadership status and position, to which Jesus responded: "I' $m$ telling you once and for all, that unless you return to square one and start over like children, you're not even going to get a look at the kingdom, let alone get in. Whoever becomes simple and elemental again, like this child, will rank high in God's kingdom" (Bible, Matthew 18:4).

\section{Practical Implications}

Whether articulated or not, every worldview or system of thought, philosophy or religion begins with some ultimate purpose or principle which shapes everything that follows (Kim et al. 2012). In the light of the preceding discussion, what are some Jesus-centred practical implications for leading ethically in organizations? Here we offer five ways in which following the example and teaching of Jesus might make a grassroots difference in the workplace.

\section{Questioning Dubious Practice Rather than Staying Silent}

Some work environments are sublimely effective in muting opposition but, as Sinclair states: "we almost always have some power to act" $(2008$, p. 78$)$ and follower collusion is often the result of individuals not listening to their emotions (or what have been termed noticing skills ${ }^{9}$ ). These

\footnotetext{
${ }_{9}$ In his book, The Power of Noticing: What the Best Leaders See, Max Bazerman notes that even with his expertise in behavioural psychology, he only recently realized that his own noticing skills were "truly terrible." "Hired a few years ago as an expert witness for the Department of Justice in what was to be the largest-ever lawsuit against the tobacco industry, Bazerman says that just before he was due to testify, he felt pressured by the government to water down written testimony he had submitted to the court in which he
}

may be in the form of cognitive doubts or more visceral unease to the point of nausea, which signal to us in palpable ways to be suspicious of and resistant towards those that lead them (Tomkins 2015)? A typical SAW proposition is that, having clarified their own ethical stance, spiritual leaders then proceed to transmit their wisdom and insights to conformist followers (Western 2008). This is both undesirable (as would any attempt to inflict our worldviews on another would be) and unrealistic (over-estimating as it does the passivity and powerlessness of followers), but nevertheless hugely tempting for those who enjoy influential status and/or gravitas in an organization. It is perhaps for this reason that Jesus called his disciples to be as "shrewd as snakes and as inoffensive as doves" (Bible, Matthew 10:6).

However, when organization values go awry or corrupt practices are perpetrated, leadership needs to be exercised in resistance, interruption or subversion (Sinclair 2007; Conroy 2010). Indeed, the discourse of spirituality has often been invoked as a critique of materialism: offering a space where inequality, discrimination or malpractice is highlighted and exposed from a different perspective. Such Christian ethical opposition may be revolutionary like liberation theology in Latin America (Guttierez 1973), emancipatory as in postmodern Christianity's critique of the church and its power structures (Frost and Hirsch 2013) or empowering by advocating that each individual pursue their unique spiritual path and not follow sheep-like (Scazzero 2011). Each is a case of following Jesus' exhortation: "You're here to be salt-seasoning that brings out the God-flavours of this earth. If you lose your saltiness, how will people taste godliness?" (Bible, Matthew 5 v 13).

\section{Example}

In her biography of The Journey of a Corporate Whistleblower, Cynthia Cooper, who blew the whistle on fraudulent activities at World.com, states on many occasions that she drew strength from her faith in the Bible and regular church services as well as from the support of family and friends during the most turbulent times of the investigations. When asked point-blank in an interview with TIME whether she would blow the whistle again, Cooper replied,

\section{Footnote 9 continued}

recommended structural changes to the tobacco industry. While the request seemed odd and vaguely unsettled him, Bazerman, distracted by other stresses and uncertain whether the request was corrupt, didn't act on those feelings at the time. It wasn't until six weeks later, after reading that another expert in the case said that he too had been pressured to alter his testimony, that he realized he had failed to notice that the gravity of the situation - possible witness tamperinghad called for decisive action." http://news.harvard.edu/gazette/story/ 2014/08/missed-opportunities/ accessed 7th Oct 2014. 
"Yes, I would. I really found myself at a crossroads where there was only one right path to take" (Ripley 2008). Despite the suffering she endured, Cooper firmly maintains that the greater good of blowing the whistle far outweighs its personal costs (Cooper 2009). This resonates well with the self-sacrifice exemplified in Jesus, who offers himself on behalf of the many, but who also hopes for a resurrection to a higher form of life as a result of his self-sacrifice, both for himself and all who follow him.

\section{Embracing Work as Calling Rather than a Job}

To the instrumentality of workplace spirituality, propounded by SAW writers, Case and Gosling posit two alternative possibilities: one is the spiritual organization as an ideal type, “... a potentially liberating notion which acknowledges the resurgence and plurality of grassroots spiritualities... to assist employees finding meaning in their lives through work" (2010, p. 276). The spin that Jesus puts on this is that it is less about choosing a job, and more about responding to a vocation (or call); as a corollary to this, the space in which this is worked out is not confined to an organization or even a profession but is more a way of life. This is how he saw his own life, explaining to his bewildered disciples who were wondering how he sustained himself: "the food that keeps me going is that I do the will of the One who sent me, finishing the work he started" (Bible, John 4:34). He modelled this redemptive work to his followers during his ministry by feeding the hungry, welcoming the stranger, clothing the poor, tending the sick and releasing captives; stated that healing relationships, reconciling enemies and bringing peace to a troubled world was part of their community mandate (Bible, Matthew 5:9). The work organization may seem an unlikely place for such activities, but only because the essential humanity of our organizations has long since been lost (Shymko 2015) and 'work' for many employees can be likened to exile (Yuk-Kwan Ng 2015). We would suggest that the spiritual organization is one where these qualities are recovered or at least pursued alongside the more material goals of good service and sustained profitability.

\section{Examples}

Italian journalist Roberto Mazzarella made it his job to create a culture of care for the other and promote the share of profits to restore hope from the oppressive hand of the "Mafia" in the region of Sicily-southern Italy. Mazzarella's resolve was strengthened following the death of Judge Paolo Borsellino, the Italian anti-Mafia magistrate killed by a Mafia car bomb in Palermo in 1992. Another Italian, also motivated by Jesus, was Chiara Lubich, one of the most influential women in the world of Catholic social justice and founder of the grassroots religious movement Focolari: "Small in stature, a gifted speaker and author of many spiritual books as well as her Word of Life newspaper columns, she was guided by her conviction that Jesus was alive in the world; her determination to follow the example of the crucified and forsaken Christ by siding with the poor and marginalized; her loyalty to the church." (Stanford 2008).

\section{Thinking Theologically Rather than Materially}

So, the idea of an organization whereby individuals find meaning in their lives through work may not be so unreal. Indeed we might push this further. By invoking spiritual and theological lenses, the very orthodoxy of neoliberal, capitalist organizations may be challenged. Dyck and Wiebe (2012) examine how views of salvation in Western Christianity have changed through four eras of history and how these changes are associated with variations in organizational practices. The value of this analysis, which does not presume religious allegiance nor require acceptance of the sacred scriptures in question, is that it creates the opportunity to learn from a theological perspective. Given that organization studies touches on matters of human wellbeing and motivation in the workplace, on oppression and emancipation, on power and powerlessness on organizational purpose and meaning, it is perhaps not surprising that theology can speak to such matters and prompt us to reframe modern organization theory: such a theological turn allows scholars to develop alternative ways of seeing organizations "and practice based on concepts that transcend contemporary management theory" (2012, p. 320).

A second alternative to instrumentalizing spirituality raised by Case and Gosling (2010) is the view that spirituality and the workplace are incommensurate and that any intersection between them is incidental, just one other site among many where spiritual journeys may or may not be pursued. A Jesus-centred theology ${ }^{11}$ would find this problematic because human work is deemed to be potentially reflective of God's work, comprising (i) the creation of things which have value and endure, (ii) sustaining that

\footnotetext{
${ }^{10}$ She also inspired the idea of Loppiano lab, a concrete experience of communication and collaboration in an economy of communion among diverse people according to age, status, traditions, culture and faith, based on the evangelical teachings (www.loppiano.it).

${ }^{11}$ In fact, there are a number of views concerning Christianity and society which have arisen over the centuries: Jesus in opposition to, in agreement with, in tension with and above culture. However, the view that Jesus Christ is the transformer of culture was at the heart of Reformation spirituality and is arguably the most mainstream today. "This attitude is characterized by the belief that although there is often a conflict between faith and work, the latter can be transformed by the former when it is recognized as being part of God's plan for humankind" (Westcott 1996, p. 68).
} 
which already exists and (iii) redeeming that which requires healing, reconciliation and repair. As well as modelling this in his own life (see above), Jesus instructs his followers to not only enjoy the benefits of work but to use these in the growth and development of themselves and those around them. In current circumstances: "these purposes are not easily achieved, for the work of many is degrading, inhuman and meaningless. Yet the possibility to fulfil these purposes is always present, no matter what the task is; for work is the gift from God, and work-through Christ—can be transformed into worship and devoted service" (Westcott 1996, p. 47). This is, subtly but significantly, not a case of spirituality being pressed into the service of an organization's mission as a means to an end, as SAW critics maintain; rather it is a re-framing of workplace relations and systems as the central issue, calling for them to be mutually respectful, creative and diversity-conscious... a by-product of which may well be more effective and energized leadership-followership.

\section{An Example}

In her study of 21 Christian SME owner-managers in the UK and Germany, Werner reports that ... "the Christian belief that everyone is made in the image of God and that everyone is created equal"-acted as a guidance to Christian owners of SME to treat each one (customers, suppliers and employees) in a fair way, irrespective of the size of business, the quantity of supply and the role in the hierarchical ladder. Likewise the specifically Christian rationale for stewardship, service for the community and (God-given) gifts and talents: "led to engaging in environmentally friendly practices, putting service before profit and being concerned about the use and development of employees' gifts and talents" (2008, p. 458).

\section{Maintaining Ethical Purpose Rather than Bowing to Market Pressure}

Christ-centred ethical leadership speaks to the heart of the way contemporary firms, enterprises and networks organize themselves. On the one hand, we have well-established organizational forms like bureaucracy becoming increasingly outmoded and cumbersome, although we should note that dismantling them could lead to the disastrous weakening of positive values like accountability, loyalty and rule-governed action (du Gay 2000). On the other hand, we have more ambiguous, fragmented and structurally diverse 'workspaces', populated by multiple actors and agencies each pursuing partisan interests or market-driven agendas. Even distributed leadership, which appears to offer greater democracy and participation, can disguise institutionalized power inequalities (Bolden et al.
2009). More than ever then, an ethically based approach to leadership is called for. Salient to this is MacIntyre's work on virtue ethics (1985) where he draws on Aquinasian and Augustinian Christian roots. Conroy (2010) develops a strong case for re-balancing the role of leaders to include an ethical dimension and purpose (Kempster et al. 2011) to their work. Although not known for his support for the management profession in his original thesis, MacIntyre has more recently remarked: "the making and sustaining of forms of human community itself has all the characteristics of a practice, and moreover of a practice which stands in a peculiarly close relationship to the exercise of the virtues ..." (2009, p. 194).

\section{An Example}

Moore (2008) suggests that this 'sustaining' role is the domain of senior managers as leaders in a community (or an institution). These are individuals who no longer take a role in the core practice but now represent the institution that houses the practices; these 'leaders' have a unique opportunity to exercise virtuous leadership by protecting the practices from the potentially corrupting influences of power, status or money. "By focussing on the core practice, ensuring its sustenance and pursuit of excellence, managers move from manipulators to participants" (Moore 2008, p. 505). This is exemplified in the work of Conroy (2010): he highlights the virtuous resistance narratives of senior NHS managers who protect embattled staff and their care practices from the damage that can be inflicted by marketization-based reforms (Francis 2010). Conroy cites evidence for a style of leadership that takes greater consideration of the generative practice damage that can occur when the ethical dimension is missing from change leadership practice.

\section{Being Transformed Internally Rather than Regulated Externally}

An all too common knee-jerk response to the ethical leadership vacuum is heightened regulation. The problem with many such audits, independent inquiries and the 'fresh' regulatory regimes which follow, is that the pernicious ethos that leads to unethical leadership and/or malpractice is rarely addressed. Furthermore, regulation can lead to uniformity and normalizing codes of ethics and practice which, as Dawson (2008) argues, can be blunt instruments in creating true ethical practice. It is only when virtues such as justice, mercy and faithfulness are exercised with practical wisdom (phronesis) that the twin dangers of imposed managerialist solutions at one extreme and self-serving, short-term expediency at the other, can be avoided. 
Once again, the words of Jesus are highly prescient: "You're hopeless, you religious scholars and Pharisees! Frauds! You keep meticulous account books, tithing on every nickle and dime you get, but on the meat of God's law, things like fairness, compassion and commitment-the absolute basics!- you carelessly take it or leave it." (Bible, Matthew 23:24). Here Jesus roundly condemns the leadership of his day. In their myopic efforts to count, to calibrate and to maintain orthodoxy, they were religiously missing the point! They were getting so wrapped up in measurement that the deeper matters of leadership were being overlooked. As discussed earlier, in God's economy, ethical leadership is about justice, compassion and commitment and will only happen as an individual repents and allows the inner transformation of the Holy Spirit. In the context of building moral organizational communities, Clarke and Butcher (2009) advocate the explicit acknowledgement-rather than avoidance or masking — of power relations; key attributes being stealth, negotiation and relationship management and building bottom-up support, what they term 'political leadership'. The danger is that this would appear to be susceptible to the promotion of partisan ideology and requires the counter-balance of a belief system that is avowedly 'othercentred'. It is here that Jesus' dire warnings continue to have traction for present-day leadership-consumed as it is with positive PR, social control, league-tables, benchmarking and regulation. To take the last of these, the track record of regulation introduced to address poor or morally dubious leadership is not impressive. ${ }^{12}$

\section{An Example}

The Global Reporting Index was established in the late 1990s and quickly gathered momentum as a helpful reporting framework for companies across all sectors to disclose information on their sustainability performance against an externally benchmarked standard, rather than relying on selfreport. Based on detailed analysis on the disclosure of HRMrelated information like stakeholder inclusiveness, disclosures on management issues and human rights-related issues, Roper et al. (2011) found endemic mis-reporting and poor compliance. This led the team to conclude that "All in all, this [research] suggests that motivation to disclose, overall, could be better explained by the benefits to be achieved from being seen to be doing the right thing." (2011, p. 12).

\footnotetext{
12 Policy makers time and again turn to deontological or utilitarian rule compliance in the face of moral crisis-even when similar regulatory frameworks have woefully failed. This is evident in the recent past where the effectiveness of the UK regulatory response to the 2008 banking crisis is, as yet, unknown and potentially 'inadequate' (Davies 2012, p. 206); recent attempts to reform the UK Health Services (e.g. Francis Inquiry Report 2010) have largely failed to address an endemic, top-down culture of bullying.
}

Contrast this with the down-to-earth and radical shift of ethos described by Henri Nouwen, a catholic theologian-priest. After twenty years, success as an academic at Notre Dame, Yale and Harvard, he changed vocation to work at L'Arche, a community for mentally disabled people. After a short time at the Centre, he notes that "the experience was ...the most important experience of my new life, because it forced me to rediscover my true identity. These broken, wounded and completely unpretentious people forced me to let go of my relevant self-the self that can do things, show things, prove things, build things - and forced me to reclaim that unadorned self in which I am completely vulnerable, open to receive and give love regardless of any accomplishments" (Nouwen 1989, p. 16).

\section{Conclusion}

The spiritual approaches to work (SAW) literature has rightly brought to our attention a relatively neglected dimension of our working lives, the fact that we bring not only just our minds and bodies, but also our emotions and spirits to work. The fatal flaw in this thinking, like other domains of organizational behaviour before it, has been to enlist these ideas and insights for simply functionalist purposes while ignoring or failing to engage with other discourses (Mabey 2013). In pointing this out so robustly, critics like Tourish have done us a great service. Our concern is that in doing so they have tended to direct their criticisms towards the whole bundle of SAW material, when in fact the call for spiritual approaches is made up of several disparate threads. In this paper, we have sought a more nuanced theorization by getting to the origin of one such thread: an avowedly Christian rendering of spiritual leadership. In this postmodern and post-structuralist spirituality, we find a systemic critique of both modernist religion and material secularity. By reflecting on the person of Jesus, we see how his teachings and example speak incisively - and sometimes uncomfortably-across the centuries to the heart of ethical leadership and business ethics. Perhaps surprisingly, he calls for radical non-conformity. First, to risk inner renewal arising from repentance as a doorway to personal integrity, often demonstrated by a willingness to be self-sacrificial. Then, a further stage of risk-taking in the workplace, not in order to protect or increase personal or organizational capital, status or power but to counter malpractice, to embrace work as a vocation, to think theologically, to pursue ethical purpose and to protect the excellence of core practices.

By highlighting the importance of the foundations of ethical purpose and tracing these foundations back to their premise-in this case the teachings of Jesus-we have sought show the relevance of business ethics to leadership 
in organizations. So, by emphasizing the importance of 'calling' (as we do in see "Reducing the credibility gap" section), we see that MacIntyre provides the "theoretical resources [...] for understanding and researching organizations in a way that bridges what are often regarded as separate domains of business ethics and organization studies" (Beadle 2014, p. 688). Although modernists like to see themselves as rational, guided by scientific reason alone, we all in fact arrive at - and inhabit-our worldview by faith, whether of a spiritual or philosophical persuasion. The point being that these beliefs constitute our identity, no matter how precarious and in flux these may be at a particular point in time. In our everyday organizational work, our ethics will be tested, pummelled and sifted as we reflexively bump against others with their own take on such matters; this is all part of the ongoing negotiation of power, influence and identity in leader-follower exchange. It is also another reason why a strict distinction between personal and organizational lives (what we have termed the moral person and the moral manager) is somewhat artificial. Of what value are private ethics if they do not shape our public actions, attitudes and decisions; of what worth are our public lives if they do not provoke reflexivity in ourselves, and perhaps others?

Open Access This article is distributed under the terms of the Creative Commons Attribution 4.0 International License (http://crea tivecommons.org/licenses/by/4.0/), which permits unrestricted use, distribution, and reproduction in any medium, provided you give appropriate credit to the original author(s) and the source, provide a link to the Creative Commons license, and indicate if changes were made.

\section{References}

Aiello, A., Pratto, F., \& Pierro, A. (2013). Framing social dominance orientation and power in organizational context. Basic and Applied Social Psychology, 35(5), 487-495.

Anderson, C., \& Brown, C. E. (2010). The functions and dysfunctions of hierarchy. Research in Organizational Behavior, 30, 55-89.

Bazerman, M., \& Gino, F. (2012). Behavioral ethics: Toward a deeper understanding of moral judgement and dishonesty. Working Papers Harvard Business School Division of Research, 12, pp. $1-43$.

Beadle, R. (2014). Managerial work in a practice-embodying institution: The role of calling, the virtue of constancy. Journal of Business Ethics, 113, 679-690.

Bell, E., \& Taylor, S. (2003). The elevation of work: pastoral power and the new age work ethic. Organization, 10, 329-349.

Bolden, R., Petrov, G., \& Gosling, J. (2009). Distributed leadership in higher education: rhetoric and reality. Educational Management Administration and Leadership, 37, 257-277.

Bourgeault, C. (2008). The wisdom Jesus: Transforming heart and mind-a new perspective on christ and his message. Boston, MA: Shambhala Publications.

Bragues, G. (2008). The ancients against the moderns: Focusing on the character of corporate leader. Journal of Business Ethics, $78(3), 373-387$.
Brief, A., Dukerich, J., Brown, P., \& Brett, J. (1996). What's wrong with the treadway commission report? Experimental analyses of the effects of personal values and codes of conduct on fraudulent financial reporting. Journal of Business Ethics, 15(2), 183-198.

Brown, M. E., \& Mitchell, M. S. (2010). Ethical and unethical leadership: Exploring new avenues for future research. Business Ethics Quarterly, 20(4), 583-616.

Brown, M., \& Treviño, L. (2006). Ethical leadership: A review and future directions. The Leadership Quarterly, 17(6), 595-616.

Brown, M., Treviño, L., \& Harrison, D. (2005). Ethical leadership: A social learning perspective for construct development and testing. Organizational Behavior and Human Decision Processes, 97(2), 117-134.

Carette, J., \& King, R. (2005). Selling spirituality: The silent takeover of religion. London: Routledge.

Case, P., French, R., \& Simpson, P. (2012). From theoria to theory: Leadership without contemplation. Organization, 19(3), 345-361.

Case, P., \& Gosling, J. (2010). The spiritual organization: critical reflections on the instrumentality of workplace spirituality. Journal of Management, Spirituality and Religion, 7(4), $257-282$.

Casey, D. (2002). Critical analysis of organizations: Theory, practice and revitalization. London: Sage.

Clarke, J. (2005). Working with monsters. How to identify and protect yourself from the workplace psychopath. Sydney: Random House.

Clarke, M., \& Butcher, D. (2009). Political leadership, bureaucracies and business schools: A comfortable union? Management Learning, 40, 587-607.

Collinson, D. (2006). Re-thinking followership: A post-structuralist analysis of follower identities. The Leadership Quarterly, 17, 179-189.

Conroy, M. (2010). An ethical approach to leading change: An alternative and sustainable application. Basingstoke: Palgrave Macmillan.

Cooper, C. (2009). Extraordinary circumstances: The journey of a corporate whistleblower. New Jersey, NJ: John Wiley \& Sons.

Crossan, M., Mazutis, D., Seijts, G., \& Gandz, J. (2013). Developing leadership character in business programs. Academy of Management Learning \& Education, 12(2), 285-305.

Darley, J. M., \& Batson, C. D. (1973). From Jerusalem to Jericho": A study of situational and dispositional variables in helping behavior. Journal of Personality and Social Psychology, 27(1), $100-108$.

Davies, H. (2012). Regulatory responses to the financial crisis: An interim assessment. International Journal of Disclosure and Governance, 9(3), 206-216. doi:10.1057/jdg.2012.5.

Dawson, A. (2008). Professional codes of practice and ethical conduct. Journal of Applied Philosophy, 11, 145-153.

Delbecq, L. (1999). Christian spirituality and contemporary business leadership. Journal of Organizational Change Management, 12, 345-349.

Driscoll, C., \& Wiebe, E. (2007). Technical spirituality at work: Jacques Ellul on workplace spirituality. Journal of Management Inquiry, 16, 333-348.

Driver, M. (2005). From empty speech to full speech? Reconceptualizing spirituality in organizations based on a psych-analytically-grounded understanding of the self. Human Relations, 58, 1091-1110.

DuGay, P. (2000). In praise of bureaucracy. London: Sage.

Dyck, B., \& Wiebe, E. (2012). Salvation, theology and organizational processes across the centuries. Organization, 19, 299-324.

Eisler, R., \& Montouori, A. (2003). The human side of spirituality. In R. Giacalone \& C. Jurkiewicz (Eds.), Handbook of workplace 
spirituality and organizational performance (pp. 46-56). New York: M.E Sharpe.

Ford, J., \& Harding, N. (2011). The impossibility of the 'true self' of authentic leadership. Leadership, 7(4), 463-479.

Forray, J., \& Stork, D. (2002). All for one: a parable of spirituality and organization. Organization, 9, 479-509.

Francis, RQC. (24 February 2010). Robert francis inquiry report into mid-staffordshire NHS foundation trust. London: House of Commons.

Freeman, J. (1984). The tyranny of structurelessness. London: Dark Star and Rebel Press.

Freshman, B. (1999). An exploratory analysis of definitions and applications of spirituality in the workplace. Journal of Organizational Change Management, 12, 318-329.

Frost, M., \& Hirsch, A. (2013). The shaping of things to come, innovation and mission for the 21st century church. Grand Rapids, MI: Baker Books.

Fry, L., \& Cohen, M. (2009). Spiritual leadership as a paradigm for organizational transformation and recovery from extended work hours culture. Journal of Business Ethics, 84, 265-278.

Fry, L., \& Kriger, M. (2009). Toward a theory of Being Centred Leadership: Multiple levels of being as context for effective leadership. Human Relations, 62, 1667-1696.

Fry, L., Vitucci, S., \& Cedillo, M. (2005). Spiritual leadership and army transformation: theory, measurement and establishing a baseline. The Leadership Quarterly, 16, 835-862.

Gardner, W. L., Cogliser, C. C., Davis, K. M., \& Dickens, M. P. (2011). Authentic leadership: A review of the literature and research agenda. The Leadership Quarterly, 22(6), 1120-1145.

Ghoshal, S. (2005). Bad management theories are destroying good management practices. Academy of Management Learning \& Education, 4(1), 75-91.

Giacalone, R., \& Jurkiewicz, C. (2003) (eds) Handbook of workplace spirituality and organizational performance. New York: M.E. Sharpe.

Greenleaf, R. (1971). Servant leadership. New York: Paulist Press.

Grint, K. (2000). The arts of leadership. Oxford: Oxford University Press.

Guttierez, G. (1973). A theology of liberation. New York: Maryknoll Orbis.

Harvey, D. (2007). A brief history of neo-liberalism. Oxford: Oxford University Press.

Hilton, S. (2015). More human—designing a world where people come first. London: WH Allen.

Hogeveen, J., Inzlicht, M., \& Obhi, S. S. (2014). Power changes how the brain responds to others. Journal of Experimental Psychology, 143(2), 755-762.

Horsley, R., \& Silberman, N. (1997). The message and the kingdom. New York: Grosset/Putnam.

Israel, S., Lerer, E., Shalev, I., Uzefovsky, F., \& Riebold, M. (2009). The oxytocin receptor (OXTR) contributes to prosocial fund allocations in the dictator game and the social value orientations task. PLoS One, 4(5), e5535. doi:10.1371/journal.pone.0005535.

Jackson, B., \& Parry, K. (2008). A very short, fairly interesting and reasonably cheap book about studying leadership. London: Sage.

Kaletsky, A. (2010). Capitalism 4.0. London: Bloomsbury Publishing.

Kellerman, B. (2004). Bad leadership-what it is, how it happens, why it matters. Boston: Harvard Business School Press.

Kempster, S., Jackson, B., \& Conroy, M. (2011). Leadership as purpose: Exploring the role of purpose in leadership practice. Leadership, 7(3), 317-334.

Kim, D., McCalman, D., \& Fisher, D. (2012). The sacred/secular divide and the Christian worldview. Journal of Business Ethics, 109, 203-208.
Kohlberg, L. (1984). Essays on moral development: Vol. 2. The psychology of moral development. San Francisco: Harper \& Row

Liden, R., Wayne, S., Zhao, H., \& Henderson, D. (2008). Multi-level approaches to leadership. The Leadership Quarterly, 19(2), 161-177.

Lips-Wiersma, M., \& Mills, A. (2014). Understanding the basic assumptions about human nature in workplace spirituality: Beyond the critical versus positive divide. Journal of Management Inquiry, 23, 148-161.

Mabey, C. (2013). Leadership development in organizations: multiple discourses and diverse practice. International Journal of Management Reviews, 15, 359-469.

MacIntyre. (1985). After virtue: a study in moral theory. London: Duckworth.

MacIntyre, A. (1988). Whose justice? Which rationality?. London: Duckworth.

MacIntyre, A. (2009). God, philosophy and universities: A selective history of the catholic philosophical tradition. London: Duckworth.

Mazar, N., Amir, O., \& Ariely, D. (2008). The dishonesty of honest people: A theory of self-concept maintenance. Journal of Marketing Research, 45(6), 633-644.

McGushin, E. F. (2007). Foucault's askesis: An introduction to the philosophical life. Evanston, IL: Northwestern University Press.

Moltmann, J. (2012). Ethics of hope. Minneapolis, MN: Fortress Press.

Moore, G. (2008). Re-imagining the morality of management: a modern virtue ethics approach. Business Ethics Quarterly, 18(4), 483-511.

Myers, C. (2008). Binding the strong man: A political reading of mark's story of Jesus. New York: Maryknoll Orbis.

Nair, K. (1997). A higher standard of leadership: Lessons from the life of Ghandi. San Francisco: Berrett-Koehler Publishers.

Nash, L. L. (2003a). A spiritual audit of business: From tipping point to tripping point. In O. F. Williams (Ed.), Business, religion, and spirituality: A new synthesis (pp. 53-78). NotreDame, IN: University of Notre Dame.

Nash, L. L. (2003b). A spiritual audit of business: From tipping point to tripping point. In O. F. Williams (Ed.), Business, religion, and spirituality: A new synthesis (pp. 53-78). NotreDame, IN: University of Notre Dame.

Nouwen, H. (1989). In the name of Jesus: Reflections on Christian leadership. New York: Crossroad Publishing Company.

Owen, D. (2012). The hubris syndrome: Bush, blair \& the intoxication of power. London: Politico's Publishing.

Peterson, E. (2002). The message: The bible in contemporary language. Colorado: NavPress Publishing Group.

Porth, S., Steingard, D., \& McCall, J. (2003). Spirituality and business: The latest management fad or the next breakthrough? In O. F. Williams (Ed.), Business, religion and spirituality: A new synthesis (pp. 249-262). Notre Dame, IN: University of Notre Dame.

Ripley, A. (2008). Q\&A: Whistleblower cynthia cooper. Times Magazine, February, 171, n.5

Robertson, I. H. (2012). The winner effect: How power affects your brain. London: Bloomsbury.

Roper, I., Parsa, S., \& Muller-Camen, M. (2011). Across boundaries: An interdisciplinary conference on the global challenges facing workers and employment research. British Journal of industrial Relations 50th Anniversary, London School of Economics, Dec 12th-13th.

Scazzero, P. (2011). Emotionally healthy spirituality. Zondervan: Grand Rapids.

Schaubroeck, J., Hannah, S., Avolio, B., Kozlowski, S., Lord, R., Trevino, L., et al. (2012). Embedding Ethical Leadership Within 
and Across Organization Levels. Academy of Management Journal, 55(5), 1053-1078.

Shymko, Y. (2015). The forgotten humanness of organizations. In C. Mabey \& W. Mayrhofer (Eds.), Developing leadership: Questions business schools don't ask. London: Sage.

Sinclair, A. (2007). Leadership for the disillusioned. Crow's Nest, NSW: Allen Unwin.

Stanford, P. (2008). Chiara lubich. The Guardian.com, 18 March

Tomkins, L. (2015). Can our bodies guide the teaching and learning of business ethics? In C. Mabey \& W. Mayrhofer (Eds.), Developing leadership: Questions business schools don't ask. London: Sage.

Tourish, D. (2013). The dark side of transformational leadership. London: Routledge.

Tourish, D., \& Tourish, N. (2010). Spirituality at work and its implications for leadership and followership. Leadership, 5, 207-224.

Treviño, L., Brown, M., \& Hartman, L. (2003). A qualitative investigation of perceived executive ethical leadership: Perceptions from inside and outside the executive suite. Human Relations, 55, 5-37.

Wagner-Marsh, F., \& Conley, J. (1999). The fourth wave: the spiritually based firm. Journal of Organizational Change Management, 12, 292-302.
Werhane, P., Hartman, L., Moberg, D., Englehardt, E., Pritchard, M., \& Parmar, B. (2011). Social constructivism, mental models, and problems of obedience. Journal of Business Ethics, 100(1), $103-118$.

Werner, A. (2008). The influence of Christian identity on SME owner-managers' conceptualisations of business practice. Journal of Business Ethics, 82, 449-462.

Westcott, D. (1996). Work well: Live well. London: Marshall Pickering.

Western, S. (2008). Leadership: A critical text. London: Sage.

Wright, N. (1996). Jesus and the victory of God. London: SPCK.

Wright, T. A., \& Goodstein, J. (2007). Character is not "dead" in management research: A review of individual character and organizational-level virtue. Journal of Management, 33(6), 928-958.

Yuk-Kwan Ng, R. (2015). Preparing Hong Kong managers for 'exile' at work. In C. Mabey \& W. Mayrhofer (Eds.), Developing leadership: Questions business schools don't ask. London: Sage.

Zhuravleva, E., \& Jones, G. (2006). Keep walking the road: Outgrowing our instrumental approach to workplace spirituality. Paper presented at the annual meeting of the Academy of Management, Atlanta, GA.

Zimbardo, P. (2008). The lucifer effect-how good people turn evil. London: Ebury. 